\title{
Institutional Sufism In Contemporary Pakistan: Theorizing Gender Through Practice
}

\author{
Saad Ali Khan \\ Centre of Excellence in Gender Studies \\ Quaid-i-Azam University Islamabad
}

\begin{abstract}
Sufism is a mystical thread of Islam works as cultural system creating the Sufi culture that is considered significantly/fundamentally different from other forms of Islamic traditions known as "orthodox," "high church" of Islam. Sufism is embedded within local cultural contexts impacting local norms and traditions and in return assimilating indigenous cultural values. This article aims to investigate the themes, perspective(s), paradigm(s), and worldview(s) that have not only incepted within the literature produced on the theme of gender and Sufism but also how this dynamic point of views (different vantage points) enabled understanding about the diversity within Sufi thought and praxis. The literature produced on the subject of gender and Sufism over the last several years have focused explicitly on the question of gender within the thought and practice of Islamic mysticism. Sufism's approach towards gender constituted the basis of understanding of how imagination about men, women, and Trans individuals surfaced over the period. However, there has been a lack of theoretical understanding of the question that how gender(s) (especially women) have been envisioned within the broader framework of Sufi thought and practice? Therefore the present work aims to toil towards the formulation of any theoretical perceptive that could assist in explanation, description, and prediction of the issue at hand. Based on an ethnographic case study of a woman Sufi (Mai Sahiba) and her shrine (Sahi Sharif) in Punjab (Pakistan), this article also highlights the implications of Sufi-gender worldview(s) and paradigm(s) on women's position and authority within Sufi culture of Pakistan. Mai Sahiba challenged the stereotypical imagination of women within Sufism through her thoughts and actions, but couldn't overcome the conventional notions of piety associated with women. Her life presents an interesting case study where she presented a radical imagination of being a Sufi woman (herself), and after her death, she is celebrated openly by the society challenging the traditional notions of Islamic womanhood through Sufism.
\end{abstract}

Keywords: Sufi-Culture, Gender, Sufi-Praxis, Worldviews, Women Sufis, Islamic Womanhood
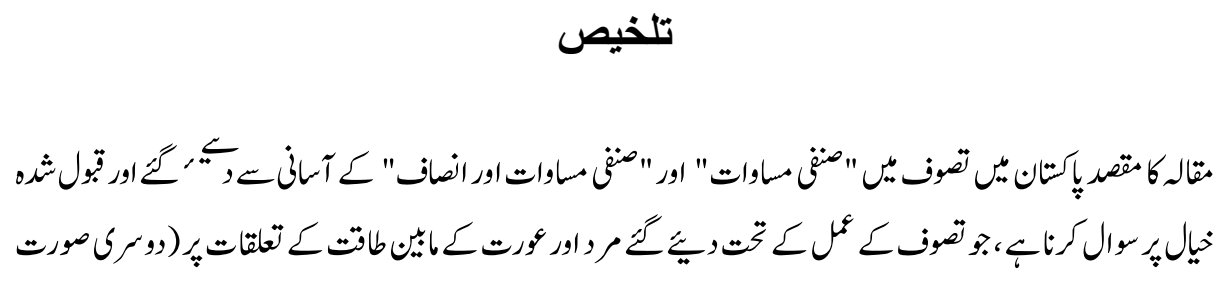


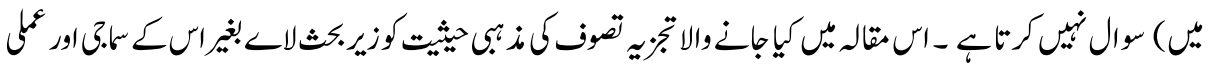

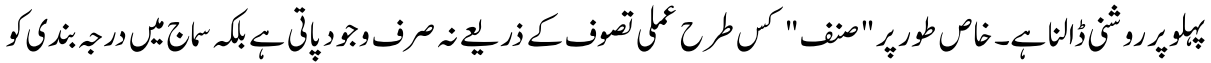

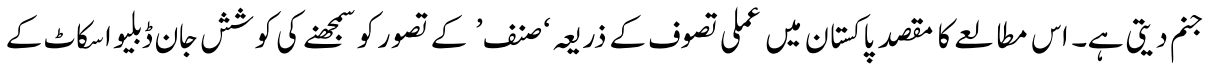

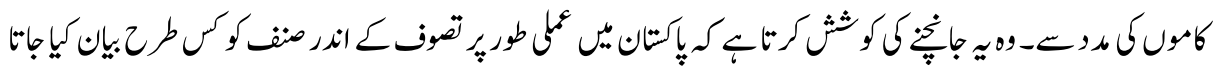

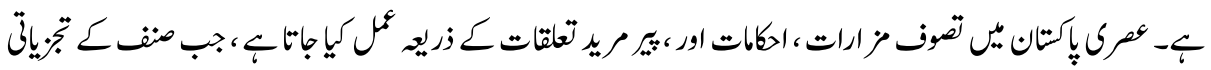

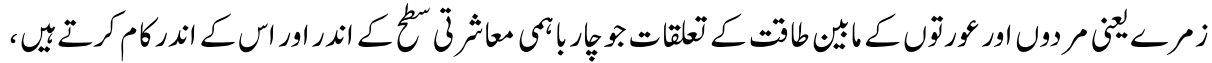

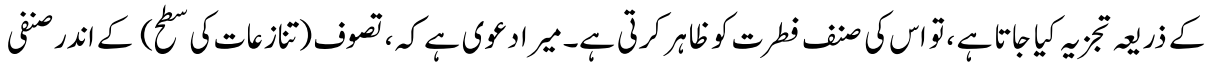

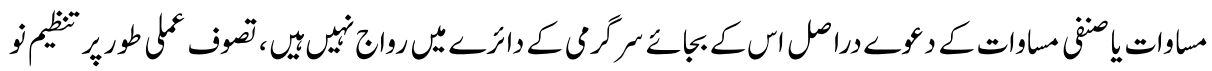

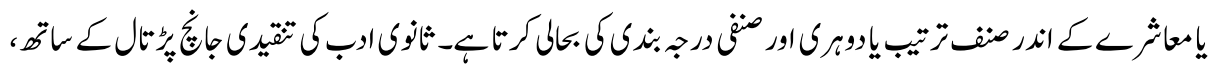

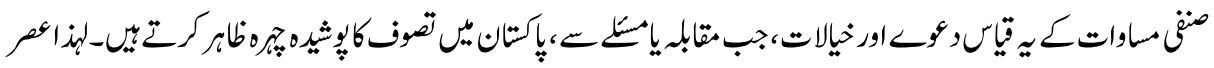

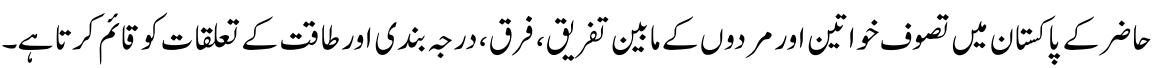

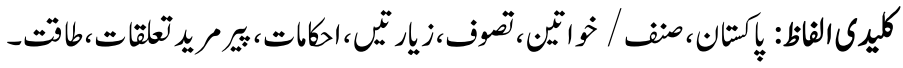

\section{Introduction}

Sufism, a term related to the word Sufi is a modern (oriental) rendition of the Arabic word tasawwuf. A Sufi is therefore a person who believes and follows tasawwuf i.e. ethical and spiritual ideals of Islam. In words of famous scholar Carl Ernst (2003) tasawwuf is generally translated as Sufism (2003: 1). History of Sufism demonstrates how individuals, men and women, hailing from all sections of society participated and constituted the world of Sufism. Interestingly Sufism is replete with examples of those men and women who have pursued, adopted and followed Sufism and known as Sufis. Debates on Sufism initially revolved around its origin, sources and persons who pursued this path. It was believed that mostly "men" pursued Sufism and were known as Sufis until Margaret Smith's (1928) work on the life of Rabia Adawiya (d. 801) started a new direction of inquiry within scholars working on Sufism. Sufism as a mystical thread of Islam also works as cultural system creating the Sufi culture that is considered significantly/fundamentally distinct from other forms of Islamic traditions like those based on orthodox, high Church of Islam. Sufism also referred to various names including Islamic spirituality (Crowther, 1996; Ernst, 2003) devotional, popular, folk, mystical, Low Church, the esoteric and perennial dimension of religion (primarily Islam) and constitutes distinctive culture that is embedded within local cultural contexts impacting local norms and traditions and in return assimilating indigenous cultural values. 
The confluence of religion and culture can be seen throughout South Asia and also evident in Pakistan.

Sufism as it flourished around the world it attracted more and more individuals and transformed into more institutionalized form. This transformation took place around $13^{\text {th }}$ century with the emergence of Sufi orders, fraternities, lineages and cults known as tariqahs or silsilahs. Historians like Annemarie Schimmel (1975), Athar Abbas Rizivi (1983) Arthur J Buheler (1998), J S Trimingham (1998) and A T Karamustafa (2007), have discussed in length this transformation within Sufism and formation of Sufi orders in different parts of the world. Sufism therefore evolved from few personalities (Sufis) or group of individuals into complex social world with its own structures and institutions. Similarly master-disciple relationship i.e. pir-murid became a central motif of Sufi life while the place of living Sufis known as khanqas attracted followers and disciples, their burial sites i.e. shrines known as mazars or dargahs transformed into center of veneration and blessings for individuals. Moreover Sufi orders (silsilas) developed in different parts of the world with the passage of time.

Sufi thought and practice in Pakistan since its inception has inspired, guided and influenced individuals who decided to follow this path. In the Oxford encyclopedia of the Islamic world: Oxford Islamic studies online, Rizwan (2010) observed that Sufism can be seen operative at two distinctive levels within society. At one level it is in populist form among rural masses, associated with unorthodox religious rituals and practices, belief in the intercessory powers of saints, pilgrimage and veneration at their shrines, and a binding spiritual relationship between the shaykh or pir (master) and murid (disciple). While at another level it manifests scholastic and intellectual tendencies and attracts more urban population based in cities that are mostly educated. For these individuals Sufism is actually the heart of Islam and Islamic revival can only be possible if Muslims seek spiritual reawakening through Sufi ideology.

However as a living tradition it constantly underwent transformation and change with time and context. Contemporary sufism in Pakistan therefore represents, as Zaman (2018) articulated a "contested terrain" that has not only been equally adored by its proponents, adherents and followers but also faced severe criticism and challenges from its detractors or in worst cases attacked by the terrorists (Shah, 2017) in recent times. Undoubtedly contemporary Sufism in Pakistan, in its practice, constituted contested terrain that requires critical analysis of its past and the transformation that took place within since its inception. This present inquiry however is not delving into uncovering theoretical transformations and changes in Sufism, rather only concerned with realm of activity or practice. 
Sufism in Pakistan has always been a part of the society, equally venerated and practiced also criticized and condemned. It has generated rich debate around its ideology and practice. These debates can be summarized as; first is the 'decline model' that argues that contemporary Sufism has lost its essence and is maligned, polluted and infiltrated by elements and ideas that are alien to its source. Proponents of this model believe that contemporary Sufism must be reformed and restored to its 'original' condition. For these individuals contemporary Sufism in Pakistan is degenerative, declined, impure, and lost its core or origination. They mostly quote one of the Sufi saying that Sufism was a reality without a name but now a name without a reality. This tendency of romanticizing past as 'golden age' questioned the authenticity of contemporary Sufism in practice. Green (2008) showed that this imagination of degeneration of Sufism from its golden age along with decline in local institutions augmented the civilizing mission of colonial power in subcontinent. Based on similar premise post-colonial state intervened and took charge of many institutions (especially shrines) within Sufism to appropriate for their own means in the pretext of reformation.

Second debate centered on the fact that contemporary Sufism as a living tradition is more assimilative and accommodative of the context and time; hence it is inevitable that change or transformation would take place within Sufi thought and practice. Following the Geertz (1973) analysis that people practice religion according to their cultural requirements, proponents of this theme believe in relevance of contemporary Sufism in the modern world. Contemporary Sufism, according to them, is devotional, indigenous, popular and societal tradition and in line with modern world. In fact this very quality of accommodation and assimilation, according to their point of view, distinguishes Sufism from traditional orthodox religious model that insists on imitation of past. Hence any change within culture of society or change in global world would also influence the nature of Sufism in practice. Moreover among these there are individuals, who also believe that Sufism is panacea for all evils in the society. Their approach towards Sufism is based on the belief that Sufism promotes tolerance, harmony, peace and universal love among all. This understanding is however deficient of analyzing and historicizing the fuller picture of Sufism especially the role of Sufis in perpetuating violence and involvement in politics and state affairs. This romanticization is partially a consequence of western imagination or depiction (orientalist) of Sufis as "antinomian, free-spirited elements of Islam" during the times of colonial period and "Sufis as potential partner" against religious fundamentalism and terrorism after incident of 9/11 and subsequent war on terror of post-colonial era.

Related to these two contradictory debates in Sufism, the issue of women is also discussed. For scholars like Ernst (2003) women presence and participation points to 
change in contemporary Sufism even a new beginning what he called as "feminist interpretations of Sufism (2003: 15)", on the other hand for scholars like Pemberton (2016) Sufism has undergone "structural and symbolic changes (2016:107)" that fundamentally paved the way of more women to participate within contemporary Sufism. She opinioned that gender inclusiveness and progressive mindedness within Sufism impacted the social world of activity positively and brought more women within realm of activity within Sufism. Similarly those who challenge the existing nature of Sufism (both reformist and extremists) presence of women is a sign that demonstrates "decline", "unIslamic" and "immoral" within Sufism. As argued by Pemberton (2016) that many Sufis practices today that involves men and women "have signaled the 'moral decline' of contemporary Sufi practice in the minds of many of its detractors (2016: 107)". Contrary to this, modernists who claim Sufism as relevant and all embracing ideology, women's presence or absence must be seen within framework of 'marginalization' or 'empowerment'. Jawad (2009) understanding of Sufism as gender egalitarian and prowomen discusses possibilities within Sufism that have opened up spaces that were traditionally purview of one gender i.e. men.

However all of these approaches or trends in my opinion conceal and obscure rather than reveal the lived practices of Sufism in Pakistan. Without problematizing and contextualizing women in Sufism, these approaches present reductionist, simplistic and generalized images of women in Sufism. Women's presence and participation within Sufism in practice is more complex and required historicizing with contextual understanding. As mentioned by Funk et al. (2018) that "considering the status of women within Sufi and Muslim contexts is not simply a matter of marginalization or "empowerment", but is far more nuanced, as women negotiate and occupy a spectrum of sphere in their enactment of Sufi traditions (2018: 213)". Similarly Shaikh (2012) argued that Sufism neither present a monolithic position on gender nor "a-historical panacea for all things beneficial for women (2009: 782)". As a critical observer of Sufism in practice in Pakistan and distancing from both these extremes, the present inquiry not only seeks to deconstruct these narratives but also aim to theorize gender within contemporary Sufism in practice.

\section{Review of Literature}

Over the last few decades, international and national scholarship/literature has resulted in a massive collection of Sufi-o-graphy. It is common parlance to discuss the question of gender/women within Sufism more often now than before. There has been the diversity of issues in this debate that has been considered in length. Ranging from conceptualization of gender within Sufi praxis to participation of women in shrines and 
from uncovering misogynistic elements within Sufi discourses to reconstituting gender dynamics through feminist endeavors are some of the recurrent themes that surfaced over the period.

Studies related to Sufism in Pakistan, both historically and anthropologically, documents women presence and participation within classical Sufism. These studies tend to focus on rituals and practices with the world of classical Sufism. Scholars like Shamim Abbass Burnay (2010) documents female voice in ritual practice of South Asian Sufism. Similarly Omar Kasmani (2014) reveals women being fakirs at the popular shrine of Sindh. However there is scarcity of available literature that analyzes the Sufi culture and institutions in Pakistan through gender lens. Throughout the world now more and more studies are dedicated towards this particular way of inquiry to uncover new aspects and analyze day to day life within Sufism.

Anthropologists exploring cultural aspects of Sufism researched various dimensions of Sufism in Pakistan. Anthropological studies on Sufism in Pakistan can be seen in a broader context of how researched on Sufism globally evolved though different stages and periods. As observed by this anthropological turn accelerated after the pioneering studies of Gellner (1981) and Greetz (1971). Therefore as argued by Green (2008);

Since the 1980s, the anthropological study of Sufi practice and of Muslim practice in the subcontinent more generally has become wellestablished and a good sample of the range of questions anthropologists address can be found in a recent anthology that prioritizes the ethnographic observation of actual Muslim practice over the prescriptive tendencies associated with the older prioritization of mystical criteria (Ahmad \& Reifeld 2004). The ethnographic focus on the external playing out of religious practice has opened up new perspectives on the dynamism of every aspect of Sufism, whether through the study of saint cults at the level of the Indian village (Assayag 1995) or of the transformation of Sufism by trans-nationalism and globalization.

Anthropological studies on Sufism in Pakistan have focused on multiple aspects of Sufism, contributing in existing body of literature on Sufism in general, however much focus has been on devotional aspects of Sufism in Pakistan. Five edited volumes on devotional aspects of Sufism that covers wide range of topics are worth mentioning here; First is Embodying Charisma: Modernity, Locality and the Performance of emotions in Sufi cults (1998) collection of essays on Sufi rituals and devotional aspects. This collection of essays dealing with India, Pakistan and Bangladesh explores Sufism as living tradition in these societies. Revolving around the theme of how Sufi rituals 
embodied as transformative acts offers "postcolonial counter narratives". Most of the works are based on rich ethnographic research analyzed while considering themes of modernity, charisma, embodiment and locality. Among the collections Lukas Werth, Pnina Werbner, Jurgen Wasim Frembgon, Katherine Ewing and Jamal Mailk's essays particularly focuses on Sufism in Pakistan. These essays cover broad themes from saint's authority to ritual practices and from gendered analysis of Sufi ideals to Sufi's paraphernalia.

Second is Islam and Society in Pakistan: Anthropological perspectives (2010). In this edited book on Islam in Pakistan, different perspectives on Muslims living Islam in Pakistani society has been collected. While addressing some of most recent trends in society vis-à-vis Islam in Pakistan, this book aimed to bring complex and diverse understandings and perspectives together. The strength of this work lies in its multidimensional approach of addressing the question of living religion in society. While authors have contributed on different aspects of Islam in Pakistan, Sufism remained a prominent thread throughout this collection. Among these essays, works of Ewing, Verkaaik, Werbner and Wolf remained most important and deals with Sufism and its multiple forms in society. While Ewing focused on how Sufism has inspired educated, urban, and business and professional class of individuals, Verkaaik's work draw attention to the processes of transformation Sufism has undergone since its inception especially in Sindh. Similarly Werbner and Wolf's contribution on Sufi rituals and practices (langar and dhamal respectively) demonstrates devotional side of Sufism in Pakistan. This edited book is undoubtedly a great contribution in presenting anthropological perspectives on religion in Pakistan.

Third is South Asian Sufis: Devotion, Deviation and Destiny (2012) which is a compilation of various chapters addressing Sufism and its various aspects in three countries of South Asia i.e. Pakistan, India and Bangladesh. Framed around the themes of devotion, deviation and destiny, this book offers analysis of change, complexity and continuity in Sufism. Presenting Sufism as vibrant religion of South Asia this book aimed to document the change and complexity within Sufism in South Asia. Contributions on Sufism in Pakistan by Hafeez-ur-Rehman Chaudhry, Uzma Rehman, Pnina Werbner, Michel Boivin and Alix Philippon document the continuity and change within Sufism in Pakistan. From shrines to politics and from identity to networking, these are main themes of these works.

Fourth is Devotional Islam in Contemporary South Asia: Shrines, Journeys and Wanderers (2015) a collection of works on "popular Islam" and its relation to collective and individual identity formations in South Asia. It also takes multidimensional approach 
on Sufism in India and Pakistan while focusing on issues of authority, spaces and identity. Shrines and Sainthood are two main aspects of devotional Islam i.e. Sufism in South Asia. Analyzing space and place through shrines, journeys and wanderers this book aimed to highlight relevance of Sufism in constructing identities both at individual and collective levels of society. While work of Omar Kasmani intersects issues of gender and authority, Alix Philippon addresses the politics of shrines and Sufi orders. Apart from those Muhammad Mubeen takes into account the evolution of a popular Sufi shrine in Punjab, while Jurgen Schaflechner sheds light on tourism and pilgrimage to women saint's tomb in Baluchistan.

Last is Islam, Sufism and everyday politics of belonging in South Asia (2016) that deals with Sufism in India, Pakistan and Bangladesh. While analyzing politics and its dynamics with individuals who belong or connect with Sufism in one way or another, this book uncovers contemporary issues and debates. Contestations over belonging whether political or social within Sufism remained largely unexplored domains. Chapters written by Uzma Rehman and Linus Strothmann are related to politics of shrines and group formation within shrines in Pakistan. While Rehman's argument is related to shrine politics of two popular shrines in Pakistan, Strothmann's analysis is linked with politics of shrines on ground through making and remaking of spaces within Sufi shrine in urban Pakistan.

Apart from these edited volumes on Sufism and its devotional aspects in South Asia and also in Pakistan, some individual anthropological works are also significant. Much of these anthropological studies on Sufism in Pakistan focused on shrines, rituals and Sufi orders. Scholars like Richard Kurin (1983), David Gilmartin (1979), Hafeez ur Rehman Chadudhry (1995), Jamal Malik (1996), Azam Chaudhary (2010), Uzma Rehman (2011), Noor Zaidi (2014), Hussain Ahmad Khan (2014), Linus Strothmann (2016), Amin Jaffer (2017) and more recently work of Umbar bin ibad (2018) all have contributed extensively on various aspects of Sufi shrines in Pakistan. From people's visitation to shrines to change in spaces of these institutions, from politics of shrine custodians to state's appropriation of shrine spaces, from gender dynamics to identity formation, these studies have addressed wide ranging issues. Similarly Sufi rituals, practices and devotional aspects collectively labeled as "physical aspects of spirituality" also gained attention of anthropologists and social historians in Pakistan. These studies include works of Shameem Abbas Burnay (2002), Regula Qureshi (2006), Richard K Wolf (2006), Jurgen Wasim Frembgon (2011), Omar Kasmani (2012) and Mikel Rytter (2016).

While analyzing the dynamics of women within Sufism, it is significant to highlight on the onset that the debate of women/gender and Sufism now constitutes an enormous body of literature being produced over the period of many years. Scholars from 
different regions of the world have operated within the different school of thoughts and disciplines, consequently generated the literature addressing the debate mentioned above. However, there have been specific themes that continually surfaced over the period, again with different vantage points. The studies/scholars who have contributed to the constitution of this body of scholarship can be categorized by their work/theme within this debate. Firstly there are scholars who have tried to identify historically the presence of women in Sufism, their status and their relationship with Sufism or in specific Sufi chains includes Schimmel (1982), Azad (2013), Dakake (2002), Murata (2007), Helminiski (2013), Abbas (2002), Elias (1988) among others. They have tried to explore historically the presence of women within Sufism and argued through their scholarly works that women have remained active and present within the thought and practice of Sufism.

Secondly, there are scholars who have contributed in documenting about specific/ individual women Sufis, their lives, and histories. This body of literature can be ranked or categorized within biographic writings about women Sufis. These scholars, who have worked extensively on this aspect, have produced works that are considered as classics including the works of Cornell (2005), Smith (2010), Schimmel (1997) among others. These studies specifically dealt with Sufi women's lives, their works and their influence on their respective societies remained some of the aspects being studied. Consequently, these studies have assisted in understanding the status of women Sufis within a specific context and time.

Thirdly the debate of Sufi literature that addresses the category/concept of women within the broader discussion of gender and mysticism can also be seen throughout the works of scholars like; Murata (1992), Shaikh (2014), Hoffman-Ladd (1992), and Kim (2009) among other scholars. These scholars have actively pursued through their work the dynamic relation and influence of Sufism on women/gender. These scholars have tried to connect theory with practice within Sufism and provided with the ideological understanding of the terms feminine, gender, sexuality and women within Sufism.

Distancing from these binary and oppositional trends regarding women issue in Sufism, I am trying to analyze 'gender' within Sufism in practice. Following set of questions will guide our discussion here in this chapter. First, how gender can be theorized or articulated through contemporary Sufism in practice in Pakistan? What is the context of contemporary Sufism in practice in Pakistan? For instance is Sufism in practice aimed to establish gender equality or it only mirrors society's established gendered order in Pakistan which is unequal and hierarchical? Similarly how Sufism in practice produce 
social relationships based on perceived differences between the sexes (Scott, 1986). Is Sufism in practice maintains hierarchical gender order and status quo or it reestablishes gender order based on equality and egalitarianism? And lastly how Sufism in practice constitutes relationships of power within social world and then how these relationships of power informed Sufi practice in return? Moreover I am interested in analyzing that how men and women are participating in world of Sufism in Pakistan. Is this social world of Sufism is different from the society in which it operates? What kind of relationship exists between men and women in Sufism in practice? What is the role of social structures, institutions or organizations of Sufism in Pakistan in creating social relations between men and women? Are these social relations different from other practiced social relations? The aim of this article is not to analyze all various aspects of Sufi culture, which in any case is not possible at the moment, rather to identify institutions within this Sufi culture that can be imagined as "critical entities/aspects for specific culture production". These points would than will act as points of engagement. Gender analysis of these institutions uncovers various embedded, implicit meanings within Sufi culture.

\section{Research Methodology and Sources}

Social research is for, about, and conducted by people. The aim of social science research is to discover knowledge related to social world. This present article has employed qualitative research methodology in order to understand the dynamics of Sufism in Pakistan. Based on critical social science paradigm that aimed to smash myths and empower people to change the society, this article relied on secondary resources related to Sufism in Pakistan. These secondary resources included books, monographs, articles, newspapers and other available literature (primarily anthropological) on the issue of Sufism in Pakistan. Over the period of time many scholars and researchers have produced valuable research on Sufism in Pakistan, however they have not addressed the question of gender in their studies. Moving further from study of virtues of pious woman in Sufism, this article presents gender theorization in Sufism. These anthropological studies on Sufism primarily focused on Sufi shrines, orders and master disciple relations. Gender as an analytical category, as defined by Joan W Scott (1986) will assist our analysis of social relations produced between individuals through Sufism in practice. The main argument is that contemporary Sufism in its context as practiced through its structures or institutions of shrines, orders (lineages) and master-disciple relations in Pakistan is gendered i.e. it treats men and women differently and this perceived and practiced difference consequently establishes gender inequality and discrimination through signification of power. In other words, Sufism as practiced in Pakistan mirrors gendered order of the society which is hierarchical, discriminatory and unequal. 


\section{Theorizing Gender through Joan Scott's Work}

I think gender continues to be useful only if it goes beyond that approach, if it is taken as an invitation to think critically about how the meanings of sexed bodies are produced in relation to one another, how these meanings are deployed and changed. The focus ought to be not on the roles assigned to women and men, but on the construction of sexual difference itself (Scott, 2010).

Joan W Scott's seminal work on "gender" revolutionized ways of understanding debates related to women and beyond i.e. gender. When she wrote gender: a useful category of historical analysis back in 1986 it certainly aimed to "pose questions associated with the influence of Michel Foucault's work (Scott, 2010). Analyzing and criticizing feminists approach towards history that aimed to question women's disadvantageous position within society, Scott (1986) opinioned that history of feminist thought is a history of refusal of the hierarchical construction of the relationship between male and female in its specific contexts.

Reviewing about the past and analyzing history, Scott presented new understanding of the term gender that came into usage. She cautioned against the essentialist and fixed understandings of 'woman' and tried to analyze the concept of gender through poststructuralist and psychoanalytical perspectives. In her erudite explanation and analysis she vehemently criticized certain historical understandings or theorization by feminists that imagines binary opposition of women-men based on their sexual difference as fixed and a-historical. Patriarchy for those feminists emerges out of this fixed, static and a-historical duality of individuals therefore must to be eradicated from its roots in order to gain equality. This understanding, according to Scott, is distortion rather aberration of social world or reality. The social world of relations is much more complex and includes many other aspects and should be seen holistically. Any analysis for that matter which excludes understanding of one aspect or another would therefore not a complete one and would always fail to convey the whole truth/reality. Scott criticizes these feminists for ignoring diverse systems of social organization including class, sexuality, race, language in their analysis of relations between men and women. According to her patriarchal understanding of inequality fails to explain its connection with other forms of structural inequalities in the society and its insistence of patriarchal inequality as 'primary' rests on physical difference only. Scott's work started with this basic premise and then presented an alternate imagination and understanding about the term gender.

She observed that the concern with gender as an analytical category emerged in the late twentieth century. Before its inception the theoretical understandings were based on the 
premise that social relations of power are considered as principle of social life. In her definition of Gender, Scott aimed to differentiate between processes that are connected and impact the social world. Gender for her is constitutive element of social relationship based on perceived differences between sexes on one hand and on the other hand it is "a primary way of signifying relationship of power (Scott, 1986). Elaborating on these interrelated but analytically different parts, she adds that the constitutive element of social world that produce human lives and relationships as well as social structures involves four interrelated elements i.e. identities, institutions, ideologies and symbols. These culturally available symbols, normative ideologies, social institutions/ organizations and subjective identities collectively constitute the social world and organize individuals into categories i.e. gendered.

Gender therefore as theorized and defined by Scott $(1986,2010)$, is a useful category through which social relation can be analyzed within a society. As an analytical category, gender can assist in understanding apparently gender neutral aspects of the society and assist in discovering ways through which gender is constructed and also impacted real lives of women and men. It will also help us uncovering inequalities, discriminations and power hierarchies constructed between women and men. Gender analysis aimed at questioning social relations between individuals i.e. women and men in contemporary society. It would reveal the impact of differences between women and men in terms of distribution of resources, access and control over resources, authority, and division of labour on construction of their gender identities. However as conceptualized by Scott, other social variable should also be taken into consideration including ethnicity, age, class, language, religion or social class. Gender construction and analysis also helps in understanding specific vulnerabilities of individual men and women. Agency and empowerment would always then conceptualize as mediums of change in an existing structure of domination or hierarchy.

\section{Discussion and Analysis: Sufism in Practice: Gendered Institutions and Contexts}

Joan's Scott's gender theorization within (level of) institutions and organizations suggest elements of institutional knowledge, practice and power. Sufism as practiced within Pakistan through institutions of shrines, orders and master-disciple relations has been analyzed through the category of gender. Within and through these institutions gendered power relation produce discrimination between individuals on the basis of social norms and rules that are practiced therein. Discrimination is therefore constructed through institutional knowledge and practice. Distribution of roles, responsibilities, powers and resources within institutions are based on social construction of differences between men and women that result in discrimination. This section aimed to identify and analyze how social inequality and discrimination is reproduced by these following Sufi institutions in Pakistan. 


\section{Sufi Shrines (mazar or dargah)}

David Gilmartin (1988) and Richard M Eaton (1984) have analyzed historically the evolution of shrines as an institution (as an Islamic institution) in Punjab (part of Pakistan) that embodied diverse local cultural identities, whose variety reflected both the diversity of ecological, social and kinship organizations in Punjab and the diversity in the spiritual needs of the people. This observation is not only true in Punjab but also in rest of the Pakistan. Each shrine is indeed embedded in the local culture and society in which those are located.

In terms of values and norms, Sufi shrines represent strong influence or color of local, indigenous society in which they are located in. As an institution, it establishes norms and practices that either resembles already prevailing or established social order or constitutes/re-constitutes its own social order within society. Interestingly some scholars considered shrines much different from other religious spaces and institutions like mosques. Kasmani's (2011) work compared and contrasted shrine with mosque and maintained that these two are both fundamentally different in terms of their functions, role and reception in the society. Based on his anthropological work carried on one of the most visited shrines in Sindh, he maintained that the shrine spaces are more inclusive and provide individuals with space of piety and devotion.

Perhaps the question of inclusion and access within shrines remained one of the contested aspects that also generated strong criticism against shrines as an institution. Arguing that, it seems (apparently) that in contrast to other religious institutions shrines are more inclusive, diverse and accessible, but when analyzed through intersectional lens, reveals an opposite and contradictory image of Sufi shrines. For instance these spaces are not fully accessible to all individuals (all sections of society for that matter) and it would be an over-estimation to consider Sufi shrines having what Jaffer (2017) called "radical democratic potential (2017: 176-77)" to challenge the established social order of the society.

In terms of its function, Sufi shrines across Pakistan are very diverse and multivalent. Scholars who worked on people visiting Sufi shrines presented multiple reasons of their visitation of Sufi shrines. Journeying (pilgrimage) to these Sufi shrines (also known as ziyarat) as articulated by Boivin (2016) provides a place to individuals "where all the different categories of population, refereeing to creeds, social groups, castes and so on, are mixed and intermingled (2016: 3)". Geographically these Sufi shrines are not only present in rural areas but also within cities and sometimes cities grew around these Sufi shrines. Based on their location within city these shrines "often play a tremendous role in the fabric of the society. If the shrine was framed by the urban, in return the urban was also framed by the shrine" (2016: 3). It is however interesting to explore how then that 
urban is framed by the shrine(s). Unfortunately there is not much work done on this aspect of shrine(s) in Pakistan.

First and foremost aspect that is related to shrines is the issue of visitation or pilgrimage (ziyarat) of these spaces. Researching on shrines, pilgrimage and related issues, Boivin (2016) argued that this visitation of individuals not only implies physical travelling but also have symbolic and spiritual meanings. Moreover he also claimed that shrine offers a space and place to different categories of society to intermingle and interact with each other. It is well documented fact that space(s) offered by Sufi shrines and people visiting Sufi shrines have multiple purposes and reasons. Most of the literature produced on aspect of visitation (ziyarat or pilgrimage) of Sufi shrines in Pakistan demonstrates that women constitute largest group of individuals who visits Sufi shrines (Charan et al., 2018; Kayani et al., 2012; Abbas, 2013; Pirani et al., 2008; Purewal \& Kalra, 2010). Analysis of these studies demonstrate that women's visitation of shrines can be fundamentally different from the way men visit and associate with shrines. Reasons and purposes to visit shrines are gendered and vary from men to women, from women to women and from men to men. However there is dearth of literature that addresses intra-gender or intersectional analysis of individuals visiting these places.

Men and women have different reasons and purposes of visiting shrines. As researched by Safdar et al. (2013), men visiting shrines were more inclined to pray for their economic well being including job security, promotion or better business. On the contrary women visitation of shrines was linked with their domestic and social life and well being. Similarly there is a dominant belief that women visit shrines because they believe in superstitions more than men. It has been demonstrated that particularly a majority of women believed in myths and superstitions. Interestingly women then imagined as individuals who have less rational capabilities and are often assumed among uneducated and poor people. As researched by Kiyani \& Farooq (2012) there is large number of females and women who visit shrines for their social and personal issues including marriages, illness, infertility, divorce and others. Women of poor social background mostly visit shrines for their economic well being. Another reason as discussed in Encyclopedia of women and Islamic cultures with reference to women pilgrimage to shrines is that visiting shrines is the only legitimate excuse for women to leave their homes (Joseph \& Nagmabadi, 2003). It points to the fact that women's mobility is also contingent upon various social variables. These ideas reaffirms the gender dichotomy of rational/emotional and body/mind where men are considered as rational and independent while women as emotional and dependent. As a result of this perceived difference between individuals, discrimination and hierarchy becomes a norm. Moreover it also shows that women and men are more confined within their traditional gender roles of 
housewives and breadwinners respectively. Women and men therefore visits shrines as according to their traditional (gendered) roles and this visitation reestablishes those gendered roles.

There is another aspect of this debate that is related to some of the prevalent discourses and stereotypes that are attached with women within society. Womanhood or manhood in society is generally informed by structures of religion, culture, economics and other social variables. However men and women faced structural constraints and pressures to manifest and comply with socially accepted images of being a man and women. In case of women, these expectations seem to be more punitive than that of men. Therefore women defying their socially prescribed images are considered as deviants, rebels and outcaste. These women are also supposed to be possessed by "evil" or "demons" and therefore brought to these Sufi shrines for "treatment". This fact demonstrates that women are considered more vulnerable and demands constant protection, treatment and surveillance from men, may it be homes or in shrines. Moreover women's sexuality is strictly guarded by narratives of honor and upheld by discourses of piety based on religious, cultural and traditional values. Reconstructing an instance from a Sufi shrine in Pakistan, Kurin (1983) observed that many women come to the shrine to be exorcised of hot demons (jinn) which may inhabit their bodies and cause them to do mischievous, lustful or vile things. Therefore men and women have different proposes for visitation of shrines. These reasons stemmed from gendered roles, expectations and responsibilities given by the society. However there is still ample space to analyze these individuals through intersectional lens considering their class, caste, ethnicity, education, status, urbanity etc. As mentioned above there is scarcity of literature that address intra-gender or intersectional analysis of individuals visiting shrines.

Secondly the issue of which is related to the shrines in Pakistan can be analyzed through gender lens. As articulated by Boivin (2016) Sufi shrine is representation of both place and space and the dialectic relation of both. In terms of their presence; hundred of shrines are present in rural as well as urban section of the society. In terms of access, mobility and division, the shrine spaces are also gendered. In most of the shrines gender segregation is maintained and in some cases women's access and entry in the main courtyard is prohibited. This internal stratification based on sexual difference is reflected in an observation that in South Asia many of the saints' tombs are internally gender segregated so that females cannot approach the actual burial site of a male saint (Joseph \& Nagmabadi, 2003). In fact the space within Sufi shrine is more or less similar to public space and mostly dominated by men. Women are often relegated within auxiliary spaces as argued by Pemberton (2006). These spaces she maintained are much different from the mainstream (public) space of shrine mostly dominated by men. This division of internal spaces reinforces the traditional gendered binary of public and private, where men are relegated in public spaces within shrines while women were given private space. This 
gender segregation of spaces within shrine is mostly informed by Islamic injunctions of pardah.

In his analysis of women fakirs of shrine in Sindh, Kasmani (2016) argued that these women have to perform their gender differently to gain legitimacy within shrine spaces. Doing gender in a manner that not only differentiate them from other men but also from their fellow women, provides these women access to gain spiritual authority. Sufi shrines according to him are much different from mosques. However close inspection of Sufi shrines reveals that although women have their space parallel to men within shrines, but their mobility is restricted and mostly assumed in hands of the men. On the other hand men can access and move within shrines independently without any restrictions or permission. For instance in her opinion article (Zakaria, 2010) the author pointed out discrimination against women even in the spiritual and mystical realm world of Sufi shrines.

Interestingly this access and authority is also reserved for men and by men. Some of these norms and values reflect gendered order of the larger society and stereotypes about women. For instance access of women to the inner most sanctuary of some of the Sufi shrines is sometimes restricted for women based on the reasons that their physical presence pollutes the shrine, to the idea that women are a distraction for men seeking spiritual experiences in the inner chambers (Joseph \& Nagmabadi, 2003). Such instances reaffirm gender stereotypes, sexist norms and gender hierarchy. Commenting on women's access into the inner courtyard or grave of Sufi shrine, Kurin (1983) argued that:

The logic of the prohibition concerns menstruation as a perceived impurity which blocks the flow of blessedness. In those shrines allowing access to women, it is often understood that menstruating women should restrain themselves from touching the tomb. According to supplicants at more restrictive shrines, outright externally imposed prohibition for all women is necessary as menstruating women are so weakened as to be deficient in rational ability and hence not be in a position to control (i.e., restrain) themselves.

These observations again reiterate the fact that shrines as institutions reproduce discrimination between men and women and also reaffirms stereotypes, taboos and misogynistic ideas about women. The spaces offered by shrines are severely unequally divided between individuals especially between men and women.

Third the social order/social relations produced and practiced within Sufi institution of shrine(s) is gendered in nature. The organization of social relations is hierarchal and based on discrimination between men and women. In most of the cases men constitute the dominant social groups exercising power within Sufi shrines. These diverse social 
groups or actors (i.e. gadi nashins, sajjada nashins, pir zada, nuqaba, mujawwars) are entirely constituted by men and wield all kinds of power(s) within this institution. They not only mediate but also represent the institution in many ways. Even in those shrines that are attributed with Sufi womens; power to rule, organize and manage affairs always remain in the hands of men. Sufi shrines thus perpetuate social differences between men and women based on sexual differences. Jaffer (2017) argued that shrine(s) constitutes undemocratic spaces based on stratification along with class, caste and gender that often mirror rather than subvert social inequalities. Working class (including men and women) is considered to be the largest section of society that associates with shrines; however the leadership is dominated by middle and upper-class men and their agendas within shrines. In terms of providing space to marginalized groups for their democratic freedom, these shrines provide limited possibilities that also mirror the dominant discourse within society. Therefore he concluded that the institutions of Sufism (shrines) in contemporary Pakistan are embedded in complex networks of power and competing interests that are not captured by the concept of counter public. Therefore, they cannot be labeled simply as sites of resistance or even of domination but offer possibility for both (Jaffer 2017).

Fourth although women constitute a large group of individual that visit Sufi shrines regularly and frequently, they also are very diverse and different from one another. In fact deconstructing the category of "women" it reveals construction of identity based on elements of class, caste, social status, religious status etc. Thus the women belonging to the family of a Sufi would be considered (hence treated) different from other women. Women belonging to Sufi family yield more power and influence over other women within Sufi shrine complex. Regarding the role and status of women within shrines, Pemberton's (2006) analysis showed that women belonging to Sufi family as mothers, spouses, sisters, daughters yield more and are privy to detailed information about the order and its members, and in many cases have detailed knowledge of the sacred texts of Islam, the teachings of the saints, and ritual procedures. Women disciples and followers are placed in lower levels of the socio-spiritual hierarchy of shrine institution. Women coming from 'outside' sometimes have to faced multiple layers or levels of discrimination and hierarchy of power. They are not only differentiated/ discriminated against men but also against the women who are "inside" of the shrine(s). Kakkar (2007) therefore rightly questioned that did women occupy positions of significance and eminence in the Sufi hierarchical order, or did they derive their identity primarily by being mothers, sisters, daughters, or wives? In most of the cases the latter is true that signifies societal imagination of women's role, status and position related to their social or traditional gender roles.

Fifth the power and authority within shrines are mostly in the hands of specific group of men who perform their functions according to their position and status within shrine 
complex. Women who visit the shrine are mostly considered as 'clients' who are associated with shrines in one way or another. In terms of articulation of norms and values that are practiced within Sufi shrines, it also reflects gender hierarchy and order based on power. Reflecting on this aspect Boivin (2016) argued:

The gender issue is related to the shrines: in the context of patriarchal societies, it is important to investigate the place of women and authority, knowing that the issue has not been addressed much yet. Paradoxically, women are often depicted as being the main and best 'clients' of the so-called spiritual guides in shrines. This is often explained by the fact that women would be more vulnerable to emotion than men. Nevertheless, the issue of how women are able to build legitimacy as a saint in a patriarchal society has rarely been addressed (Boivin, 2016).

\section{Sufi Master-Disciple Relationship (pir-murid or shaykh-salik)}

Sufism offers a unique and individualistic way of interacting with and approaching the Divine. Insistence on cultivation/purification of inner self (esoteric) would require not only personal/self commitment and efforts but also supervision, guidance and blessing of a teacher, guide, leader or master. Sufism is conceived not only as a way of transformation but refers to a constant journeying of the individual. Also known as Tariqa which means "the way or path", Sufism provides a pathway that has to be taken by individuals who will then eventually reach their destination i.e. Haqiqah or literary mean "the truth" or Divine. Individuals who thus take this path (Salook) are known as salik (seekers) or Sufis. They are also sometimes referred as murid (the one who is following a wish/desire) in Sufism. Pir-murid relationship has many aspects and is considered by many Sufis as inevitable for the practice of Sufism. Within this bonding, identities are formed by and for individuals. Sometimes these identities are ascribed and sometimes these identities are achieved.

Interestingly with the formalization of pir-murid relation the dynamics as well as characteristics of this relationship also started to change. With the passage of time more rites/rituals were added within this practice. Rules and regulations also started to take form. Although some of the classic Sufi texts address more explicitly and in detail the contours of this relationship, it was until recently that compliance with rules and regulations deem necessary. Chittick (2000) in his book summarized this relationship as a bond between two individuals that gives life to the Sufi tradition. The shaykh and disciple's relation is modeled on way of the Prophet and the companions (Bay'at ar Ridwan). For Chittick the primary concern for the shaykh is to transform inner-self of the disciples through this relationship. 
Firstly the relationship between master-disciple is always hierarchical and stratified. Master/Pir/Shaykh/murshid is considered as locus or center of this relation. Followers, disciples or murid are supposed to follow rather imitate the 'ideal life/personality' of the pir. Within this hierarchy women are never placed equal to men and always situated in the lowest ranks. This fact is evident that very rarely women assume or given or achieved the role of Sufi shaykh or master. This spiritual power and authority is linked with men and men mostly. Men assuming/achieving status/role of pir wield power and authority not only over other men in public but also over women exclusively. As Kasmani (2016) argued in his analysis of women fakirs of Sindh as an exception that seldom do women of these accounts enjoy an influence over a male in public, and neither do they, unlike fakirs of this chapter, take up roles of spiritual authority that are customarily reserved for men. Interestingly these women fakirs legitimize their spiritual authority by doing gender differently, circumcising societal and cultural notions of being a women and the same time honing some aspects of their own femininity.

As women, even if they are considered as guides or pirs, they gain legitimacy either through their traditional gendered roles of being mother, daughter, sister or wife of a male Sufi shaykh or they act as de facto guides being given authority or permission from a male Sufi shaykh. This again pointed to their dependence on male individuals for legitimacy or their compliance with traditional or cultural notions of womanhood to act as pirs. Women who are nominated as representatives or delegates (kahlifa) have their own marginal private spaces for authority and guidance. Pemberton (2006) mentioned that it is primarily due to permission (ijaza) of the male pir that can and will enable women's role in position of authority in Sufism. Without this permission women would not be able to gain legitimacy to act in any authoritative role within Sufism. Therefore spiritual power and authority is considered sole property of men of specific group.

Moreover eligibility of becoming a Sufi pir also differentiates drastically for men and women. As discussed above women are generally considered as pirs or shaykhs in mainstream Sufi orders in Pakistan. While in case of India, Pemberton's work (2006, 2011) revealed that women can possibly act as pirs (but not de jure) provided that they fulfill these conditions; they have to maintain and uphold societal notions of 'modesty' attributed to a 'woman' and gain respect, they have to practice their authority outside of 'public' realm, they have to uphold pardah i.e. veiling and seclusion and their compliance with believing in the idea that women's authority is actually accorded to her by men. While none of these conditions would ever be required for a man who want to become a pir or shaykh within Sufism in Pakistan. Women aspirants for this role then always scrutinized within Islamic legalistic interpretation i.e. based on principles of shariah. However these are more in line with culturally ascribed ideas of woman within society which is discriminatory. 
Secondly gendered imagery and notions are espoused within the institution of pir-murid since classic period of Sufism. These gendered images are still used and appropriated by Sufi orders in establishing their own ideologies, narratives and discourses about pirmurid relations. Malamud (1996) have analyzed in detail about this aspect of Sufi masterdisciple relations. Analyzing classic Sufi text, she argued that male Sufis often used gendered imagery to describe the relationship between a Sufi master and his disciple. Gendered imagery appropriated by male Sufi authors to express power, authority and domination. Malamud further explained that:

Gendered imagery was used in part to signify relationships of power and subordination. It provided our male authors with a way to describe a hierarchical relationship based on dominance and submission, and, at the same time, it helped them articulate the intimate connection between authority and dependence. When feminine imagery was applied to disciples, the dependence and subordination of the disciple were stressed, but when it was used to describe the master, it enhanced the master's power and authority; through the rhetorical appropriation of female procreative and nurturing powers. The use of feminine imagery thus could signify both authority and dependence.

It clearly reflects how power is gain through use of culturally available images of gender about men and women within Sufism. Although she argued this in context of medieval Islamic societies, such usage and appropriation of gendered imager within pir-murid relation is still prevalent in most Sufi orders in Pakistan. Not much has been researched/ documented on this aspect of Sufism within Pakistan. What need to be researched is that how these Sufi rituals and institutions consecrate hierarchy and inequality in this social world by linking its social forms to the divine will and order (Malamud, 1996).

\section{Sufi Orders (tariqa or silsila)}

Published in 1971 Trimingham's work on Sufi orders in Islam became a pioneering study of its own kind that documented origin, development, evolution and decline of Sufi orders. Sufi orders are also known as tariqas (Arabic) that literally means 'the path/way' and mystic brotherhoods. Sufi orders since their formation have played significant role not only in disseminating message of Sufis but also connecting individuals into collective organization and identities. Growth of Sufi orders also coincided with 'institutionalization' of Sufi teachings across the world during sixth/twelfth centuries. Hence Sufi orders and brotherhoods have formed networks, communities, groups and associations in different parts of the world. Some of these orders are well organized, structured and hierarchical in nature while others are less structured and hierarchical. Similarly the norms, values, ideologies, doctrines, practices, rituals and rules vary from one order to another order and even sometimes within same order having different branches or sub-orders. 
Jaffer (2017) analyzed identify formation associated with Sufi groups and gender non conformity as the dominant approach in these texts is to focus on the distinctive identity formation that emerges from the cults, orders, networks, communities or movements that are formed around Sufi saints and or/shrines. While these formations certainly offer powerful frameworks for establishing identities that may at times be in opposition to or transcend national, ethnic, caste and even religious boundaries, they tend to be largely dominated by men. In context of South Asia and especially in Pakistan most of the Sufi orders are headed/dominated by men. Men are in charge of Sufi orders and almost all major Sufi orders in Pakistan are named after their founders who were all men. Although Werbner (2007) discussed a Sufi order i.e. Azimiyya of Pakistani origin in Britain that is headed by a woman, she is in fact given authority/permission and appointed by her own shaykh to head order in Britain.

Moreover as mentioned in above section that every Sufi order is based on Sufi genealogy or silsila. These silsila is actually a spiritual lineage, genealogy and chain that contain/mention all the names of Sufi shaykhs connected with each other through spiritual bonds through initiation. Every Sufi order therefore has a 'spiritual genealogical tree' or 'shajra' that contain all the names of Sufi shaykhs and goes back to the Prophet. These Sufi orders and silsilas have never a mention of women within it. In other words a woman cannot be or have never been part of a silsila's shajra. It has been believed, assumed and practiced that spirituality pass from heart to heart (read here: from men to men). Even in Sufi orders where women are designated as shaykhas or murshidas, their names are never included in spiritual genealogy.

Women's increased participation and visibility within Sufi orders is taken with much suspicion and anxiety. For example Kelly Pemberton (2016) recently argued that, "Sufis of yesteryear, as today, have been criticized as 'immoral' for welcoming women into their circles...these have signaled the 'moral decline' of contemporary Sufi practice" (2016: 107). Interestingly this argument is not only presented by individuals who always remain critical of Sufi Islam but also from within Sufi Islam itself. Pemberton argued however that women's increasing participation in Sufi orders and gaining more public acceptance with Sufi Islam also increasingly impacting changes within gender symbolic capital/resources of Sufi orders.

\section{Conclusions}

Sufism in contemporary Pakistan is mostly practiced through institutions of shrines, orders and master-disciple relationship. Over the period of time these institutions have 
formulated their own rules and regulations, practices, symbols, ideologies, ideas, and structures. Scholars have worked on historical evolution and development of these institutions within specific contexts and time periods. While most of the studies have focused how Sufism have evolved over the period of time and how it is being practiced in contemporary times, less attention has been given to the gender aspect of these complex multifaceted institutions. Women presence, participation and visibility within these structures is often considered as their freedom, equality and accommodation, however close inspection through gender lens would reveal how power is embedded and exercised through these institutions that creates difference and discrimination between men and women. Sufism, as an ideology (discursive level), aimed to guide individuals in their quest for the Divine truth, in practice differentiates between men and women, subsequently generating inequality between the two. The Encyclopedia of Muslim women and Cultures aptly presents this in these words:

Images of sex, gender, and women in Sufism are complex, comprised of equitable, beautiful, and misogynistic depictions often derived from the very same cosmological gender images...These images are complex precisely because the same issues in the wider Muslim society are so complex. The whole of the Sufi statements must be considered in their historical and interpretative contexts to adequately access the nature of the positions taken as well as their influence on later Sufism.

More recently new research started to question the power dynamics between group of individual within these structures from gender and intersectional perspectives. Gender as an analytical category can reveal the hidden aspects of these institutions, as demonstrated in this article. Sufism as practiced through the institutions of shrines, orders and masterdisciple relations reinforces gender hierarchy between men and women. This hierarchy is closely linked with conception of power within these institutions. As articulated in a recent study (Funk et al., 2018) on contemporary Sufism, this institutionalization of Sufism (shrines, orders and master-disciple relationship) consequently generated male domination of public sphere. In the realm of practice the leadership roles are solely reserved for men within Sufism and hardly any woman is considered worthy to be known as Sufi leader in contemporary Pakistan. Through analysis of secondary resources on Sufism in Pakistan, this article has revealed that Sufism as practiced through the institutions of shrines, master-disciple and orders are reestablishing the discriminatory gender order that is part and parcel of culture in Pakistan. 


\section{References}

Abbas, S. et al. (2013). Peoples' Perceptions about Visiting Sufi Shrine in Pakistan, South Asian Studies, vol.28:2, pp.369-387.

Ahmed, Durre S. (200). Real Men, Naked women and the Politics of Paradise: The Archetype of Lal Ded. In Gendering the Spirit: Women, Religion and the PostColonial Response, New York, Zed Books, pp.155-179.

Anjum, T. (2011). Be Hell for Those Who Call Me Saiyyid: Social Stratification among the South Asian Muslims and the Sufi Worldview. Pakistan Journal of History and Culture, vol.32:2, pp.49-64.

Ansari, Sarah FD. (1992). Sufi Saints and State Power: The Pirs of Sind, 1843-1947. No. 50. Cambridge University Press, pp.1-178.

Buehler, Arthur F. (2016). Recognizing Sufism: Contemplation in the Islamic Tradition. IB Tauris.

(1998). Sufi Heirs of the Prophet: The Indian Naqshbandiyya and the Rise of the Mediating sufi shaykh. Univ of South Carolina Press.

Bruinessen, M.V. \& Howell, J.D. (2007). Sufism and The 'Modern' in Islam. New York: I.B Tauris.

Charan, I.A., Wang, B. \& Yao, D. (2018). Cultural and Religious Perspective on the Sufi Shrines. Journal of Religion and Health, vol.57:3, pp.1074-1094.

Crowther, Jonathan, ed. (1996). Oxford Advanced Learner's Dictionary of Current English, 5th ed. Oxford: Oxford University Press, pp. 1146.

Chittick, William C. (2000). Sufism: A Short Introduction. One World Publications Limited

Eaton, Richard M. (1990). The Political and Religious Authority of the Shrine of Baba Farid in Pakpattan, Punjab. Ed. B.D. Metcalf, Moral Conduct and Authority: The Place of Adab in South Asian Islam, Berkeley, pp.338-342.

Ernst, Carl W. (2003). Following Muhammad: Rethinking Islam in the Contemporary World, The University of North Carolina Press Chapel Hill, London, pp.164. 
Farooq, A. \& Kayani, A.K. (2012). Prevalence of Superstitions and Other Supernatural in Rural Punjab: A Sociological Perspective. South Asian Studies, vol.27:2, p.335.

Geaves, Ron \& Theodore Gabriel, eds. Sufism in Britain. A\&C Black.

Geertz, C. (1971). Islam Observed: Religious Development in Morocco and Indonesia, vol. 37. University of Chicago Press.

Gilmartin, D. (1988). Empire and Islam: Punjab and the Making of Pakistan. Berkeley: University of California Press.

Green, Nile. (2008). Making Sense of 'Sufism in the Indian Subcontinent: A Survey of Trends. Religion Compass, vol.2:6, pp.1044-1061.

Hermansen, Marcia. (2000). Hybrid Identity Formations in Muslim America: The Case of American Sufi Movements 1. The Muslim World, vol.90:1/2, pp.158-197.

Hussain, R. "Pakistan." In The Oxford Encyclopedia of the Islamic World. Oxford Islamic Studies Online, http://www.oxfordislamicstudies.com/article/opr/t236/ e0616 (accessed August 16, 2018).

Charan, et al. (2018). Cultural and Religious Perspective on the Sufi Shrines, Journal of Religion and Health, vol.57:3, pp.1074-1094.

Jawad, Haifaa (2006:156). Female Conversion to Islam: The Sufi Paradigm, in Karin van Nieuwkerk, 2006. Women Embracing Islam: Gender and Conversion in the West. University of Texas Press: Austin

Karamustafa, Ahmet T. (2007). Sufism. Edinburgh University Press.

Klinkhammer, Gritt. (2009). The Emergence of Transethnic Sufism in Germany. Sufis in Western Society, pp.130-147.

Knysh, Alexander. (2017). Sufism: A New History of Islamic Mysticism. Princeton and Oxford: Princeton University Press.

Meier, F. (1976). The Mystic Path. The World of Islam: Faith, People, Culture, pp.117-140.

Philippon, A. (2006). Bridging Sufism and Islamism. ISIM Review, vol.17:2, pp.16-17. 
(2014). A Sublime, Yet Disputed, Object of Political Ideology? Sufism in Pakistan at the Crossroads. Commonwealth \& Comparative Politics, vol.52:2, pp.271-292.

Pirani, et al. (2008). The Search for Healing at a Muslim Shrine in Pakistan, Mental Health, Religion and Culture, vol.11:4, pp.375-386.

Rozehnal, Robert. (2007). Islamic Sufism Unbound. Politics and Piety in Twenty-First Century Pakistan. New York.

Scott, Joan W. (1986). Gender: A Useful Category of Historical Analysis, The American Historical Review, Oxford University Press, vol.91:5, p.1067.

(2010). Gender: Still a Useful Category of Analysis? Diogenes, vol.57:1, p.10.

Schimmel, A. (2003). My Soul is a Woman: The Feminine in Islam. Bloomsbury Publishing USA.

Shah, S. (2017). Sufi Shrines Under Attack in Pakistan - A Chronology. Accessed August 15, 2018, https://www.thenews.com.pk/print/186913-Sufi-shrines-underattack-in-Pakistan-a-chronology

Sulamī, M. H. \& Cornell, R. E. (1999). Early Sufi Women: Dhikr An-Niswa AlMutaàabbidāt Aș-Süfiyyāt. Louisville, KY: Fons Vitae.

Trimingham, J. Spencer. (1998). The Sufi Orders in Islam. Oxford University Press.

Werbner, Pnina. (2003). Pilgrims of Love: The Anthropology of a Global Sufi Cult. Indiana University Press.

Werbner, P. (2010). Beyond Division: Women, Pilgrimage and Nation Building in South Asian Sufism. Women's Studies International Forum, vol.10, pp.374-382.

Werbner, P. (2007). Intimate Disciples in the Modern World: The Creation of Translocalamity among South Asian Sufis in Britain. In Sufism and the "modern" in Islam, London: I.B.Tauris, pp.195-216.

Zaidi, N. A (2014). Blessing on Our People: Bibi Pak Daman, Sacred Geography, and the Construction of the Nationalized Sacred. The Muslim World, vol.104, pp.306-335. 
Zaman, M.Q. (2018). Islam in Pakistan: A History, Princeton: Princeton University Press, p.195.

Zia, A. S. (2018). Faith and Feminism in Pakistan: Religious Agency or Secular Autonomy? Sussex: Sussex Academic Press.

Zilli, I. A. (1977). Early Sufi Thought in India. In Proceedings of the Indian History Congress, vol. 38, pp. 279-291.

Saad Ali Khan is Lecturer in the Centre of Excellence in Gender Studies, Quaid-i-Azam University Islamabad. 